\title{
CAN WE PREDICT SPHAEROPSIS SAPINEA OUTBREAK BY MONITORING FUNGAL DIVERSITY IN AUSTRIAN PINE PLANTATIONS?
}

\author{
MOŽEMO LI PREDVIDJETI ZARAZE GLJIVOM \\ SPHAEROPSIS SAPINEA PRATEĆI RAZNOLIKOST GLJIVA \\ U ŠUMSKIM KULTURAMA CRNOGA BORA?
}

\author{
Željko ZGRABLIĆ ${ }^{1 *}$, Hrvoje MARJANOVIĆ², Danko DIMINIĆ3
}

\begin{abstract}
Summary
Fungal diversity plays an important role in forest ecosystems stability as well in the health status of mycorrhizal forest trees. At research area in Istria, Croatia, pathogenic fungus Sphaeropsis tip blight (Sphaeropsis sapinea (Fr.) Dyko et Sutton) caused substantial damage in Austrian pine (Pinus nigra J. F. Arnold) plantations during the last decades. This research continues on previous done in Austrian pine plantations on predisposition to S. sapinea infections, where site and stress conditions were determined as key factors, but also, the ectomycorrhizal (ECM) fungi were confirmed as biological indicators of the health status in selected plantations. We analyzed fungal diversity of Austrian pine plantations to determine the dependence of species richness and its diversity index, both for total and ECM species only, in relation to S. sapinea infection rate and crown transparency of selected trees. Fungal samples were collected during 2013 at nine permanent research plots in autumn season. Their total and ECM species richness and diversity index were correlated to Sphaeropsis tip blight infection level and crown transparency. Our results did not confirm the hypothesis that Austrian pine plantations with higher total species richness and its diversity index are more resistant to S. sapinea infection nor to crown transparency. Oppositely, ectomycorrhizal species richness and its diversity index might be used as good biological indicators of $S$. sapinea presence and crown transparency of studied plantations.
\end{abstract}

KEY WORDS: Pinus nigra, Sphaeropsis sapinea, crown transparency, integrated forest protection, species richness, Shannon index, ectomycorrhizal fungi

\section{INTRODUCTION}

UVOD

Sphaeropsis tip blight (Sphaeropsis sapinea (Fr.) Dyko et Sutton) caused a substantial damage and dieback of Au- strian pine (Pinus nigra J. F. Arnold) plantations in Istria region, Croatia, through the last three decades. The dieback caused ecological and economical loses, e.g. loss of biodiversity, change in soil microclimate, increased erosion processes and loss of timber. Although the pathogen itself was

\footnotetext{
${ }^{* 1}$ Dr. sc. Željko Zgrablić, Ph.D., Croatian Forest Research Institute, Research Center for Other Forest Goods and Services "Josip Ressel", Hrvatski šumarski institut, Centar za općekorisne funkcije šuma "Josip Ressel", 154. brigade Hrvatske vojske 2, HR-52000 Pazin, Hrvatska, zeljkoz@sumins.hr,

2 Dr. sc. Hrvoje Marjanović, Ph. D., Croatian Forest Research Institute, Division for Forest Management and Forestry Economics, Hrvatski šumarski institut, Odjel za uređivanje šuma i šumarsku ekonomiku, Trnjanska cesta 35, HR-10000 Zagreb, Hrvatska, hrvojem@sumins.hr,

${ }^{3}$ Prof. dr. sc. Danko Diminić, Professor, Ph.D.,Univeristy of Zagreb, Faculty of Forestry, Department of Forest Protection and Wildlife Management, Sveučilište u Zagrebu, Šumarski fakultet, Zavod za zaštitu šuma i lovno gospodarenje, Svetošimunska 25, HR-10000 Zagreb, ddiminic@sumfak.hr.
} 
studied and described in details (Diminić 1997) it was unclear which abiotic and biotic factors are detrimental for disease outbreak. Results of Diminić et al. $(2003 ; 2012)$ revealed the predisposition of Austrian pine to Sphaeropsis tip blight infection depending on bedrock, soil type and water availability. Draught was also highlighted as a crucial stress factor in north Dalmatia, Croatia, which predispose pines for different pathogen attack (Pernek et al. 2012). Afterwards, Austrian pine plantations with higher ratio of ectomycorrhizal (ECM) fungal species in the total number of recorded species were confirmed as more resistant to $S$. sapinea infection (Zgrablić et al. 2015). Although fungi play a crucial role in forest ecosystem stability acting as saprotrophs, symbionts or parasites (Zgrablić et al. 2014), they still represent a large group of organisms that lack fundamental knowledge of their diversity on global scale (Kuyper 1994; Tkalčec et al. 2008). Fungal diversity on Earth is estimated to 1.5 up to 7 million species, with many species still waiting to be described (Blackwell 2011; Kuyper \& Giller 2011). This confirms that biodiversity as a global concept of variety of life, is crucial for sustainable functioning and survival of ecosystems on Earth (Perini \& Laganà 2004). According to various authors, a healthy forest ecosystem contains $40-60 \%$ of mycorrhizal species and fruit bodies in the total count of present species and their fruit bodies (both mycorrhizal and saprobic) (Arnolds 1991; Fellner 1989, 1993; Fellner \& Peškova 1995; Egli 2011). It is well known that mycorrhizal plants are more resistant to biotic and abiotic stress, transplantation stress, soil pathogens, high temperatures, salinity and extreme $\mathrm{pH}$ soil conditions (Kendrick 2000; Palermo et al. 2003; Perotto et al. 2013).

Subsequently, many studies were conducted to describe the performance of inoculated seedlings and mycorrhizal communities of forests damaged by air pollution. Resistance of Norway spruce seedlings roots with different mycorrhizal inoculums were tested to prevent the attack of honey fungus (Armillaria (Fr.) Staude) in the Czech Republic. Treated seedlings showed significantly higher dimensions than the control sample even in the areas of honey fungus high infection rate (Holuša et al. 2009). Different authors described the decline of mycorrhizal fungal communities caused by air pollutants (Termorshuizen \& Schaffers 1987, 1989; Arnolds 1991; Fellner 1993; Fellner \& Pešková 1995; Matočec et al. 2000; Pešková 2005, 2007; Kraigher et al. 2007). Deciduous and coniferous forests were studied in Czech Republic where stands were grouped in three classes according to their health status (latent, acute and lethal). The results clearly indicated the connection of trees crown transparency and the number of mycorrhizal species and their fruit bodies. Furthermore, it was determined that percentage of active and non-active mycorrhiza on root tips strongly depends on host plant health condition, same as on health condition of entire forest (Fellner 1993; Fellner and Peškova 1995). Studies of
Quercus ilex L. forests from Italy, where selected trees were grouped in three different health classes, showed only $25 \%$ of common fungal species between the classes. This indicated that altered health conditions influence the ECM community, meaning that a healthy tree can choose its mycorrhizal partner less demanding in terms of nutrients, while the infected tree loses this possibility (Druebert et al. 2009; Montecchio et al. 2009). Mycorrhizal communities of sweet chestnut (Castanea sativa Mill.) forests in Italy affected by ink disease (Phytophthora cambivora (Petri) Buism.) were studied, where selected trees were classified according to ink disease symptoms in three classes. Oppositely than expected, number of mycorrhizal morphotypes on chestnut roots was not significantly different between the classes. However, cluster analyses revealed that with increasing symptoms of ink disease, the ECM community was more similar, whereas asymptomatic trees differed significantly from symptomatic classes and inside the group (Scattolin et al., 2012).

Despite to all above mentioned results, there is a substantial gap of knowledge on interaction between fungal diversity as a potential indicator of Austrian pine plantations resistance towards disease outbreak and S. sapinea infection rate. S. sapinea is a very specific pathogen that causes the damage or a dieback of Austrian pine in natural habitats or plantations all over the world (Swart \& Wingfield 1991; Diminić 1997). Its principal characteristic is the possibility to attack all parts of the tree that had suffered abiotic stress, mainly draught (Diminić et al. 2012). The pathogen can live as an endophyte in the healthy pine needles without causing any damage for years, but abiotic stress can act as a trigger to activate its parasitic stage of life (Stanosz et al. 2001; Deriu 2010).

Among Austrian pine plantations in Istria, we observed differences in species composition and richness. Considering the principles of integrated forest protection as more sustainable and environmentally less harmful method in relation to conventional use of pesticides in forest protection (Feldmann et al. 2003), in this research, for the first time, we studied macrofungal diversity as a potential indicator of tree health status and S. sapinea infection rate, respectively. From the present knowledge and observations, we draw our hypotheses that plantations with higher diversity of fungal species (species richness), are more resistant to S. sapinea infection outbreak. More precisely, we tested the total and ECM species richness, and Shannon diversity index for the total count of species and for ECM species only, in relation towards an average number of $S$. sapinea pycnidia on needles and an average crown transparency of Austrian pines.

\section{MATERIALS AND METHODS MATERIJALI I METODE RADA}

Fungal samples were collected in Istria region (Croatia), Forest administration Buzet, at nine permanent research 
Table 1: Characteristics of nine study plots according to bedrock, soil type, age, slope, aspect and altitude.

Tablica 1: Karakteristike devet istraživanih ploha s obzirom na matičnu podlogu, tip tla, starost, nagib, ekspoziciju i nadmorsku visinu.

\begin{tabular}{|c|c|c|c|c|c|c|}
\hline $\begin{array}{l}\text { Plot } \\
\text { Ploha }\end{array}$ & $\begin{array}{c}\text { Bedrock } \\
\text { Matična podloga }\end{array}$ & $\begin{array}{l}\text { Soil type } \\
\text { Tip tla }\end{array}$ & $\begin{array}{l}\text { Age (year) } \\
\text { Starost }\end{array}$ & $\begin{array}{l}\text { Slope }\left({ }^{\circ}\right) \\
\text { Nagib }\left({ }^{\circ}\right)\end{array}$ & $\begin{array}{c}\text { Aspect } \\
\text { Ekspozicija }\end{array}$ & $\begin{array}{c}\text { Altitude }(\mathrm{m}) \\
\text { Nadmorska visina }(\mathrm{m})\end{array}$ \\
\hline Previž & & $\begin{array}{l}\text { Eutric Cambisol } \\
\text { Eutrično smeđe }\end{array}$ & 30 & $20-32$ & E-SE & 338 \\
\hline Lesišćina & $\begin{array}{l}\text { Flysch } \\
\text { Fliš }\end{array}$ & $\begin{array}{l}\text { Eutric Cambisol } \\
\text { Eutrično smeđe }\end{array}$ & 20 & $10-24$ & S-SE & 269 \\
\hline Paz & & $\begin{array}{l}\text { Eutric Cambisol } \\
\text { Eutrično smeđe }\end{array}$ & 30 & $10-18$ & S-SW & 248 \\
\hline Mali Golji & & $\begin{array}{l}\text { Terra rossa } \\
\text { Crvenica }\end{array}$ & 60 & $2-5$ & S-SE & 309 \\
\hline Trstenik & & $\begin{array}{l}\text { Calcocambisol } \\
\text { Smeđe na vap.-do. }\end{array}$ & 70 & $11-23$ & N-NE & 772 \\
\hline Ripenda & Limestone-Dolomite & $\begin{array}{l}\text { Calcocambisol } \\
\text { Smeđe na vap.-do. }\end{array}$ & 78 & $15-22$ & W-SW & 347 \\
\hline Lovranska Draga & Vapnenac-dolomit & $\begin{array}{l}\text { Calcocambisol } \\
\text { Smeđe na vap.-do. }\end{array}$ & 90 & $3-35$ & $E$ & 518 \\
\hline Trošti & & $\begin{array}{l}\text { Terra rossa } \\
\text { Crvenica }\end{array}$ & 60 & $5-10$ & 0 & 388 \\
\hline Kurbino brdo & & $\begin{array}{c}\text { Calcocambisol } \\
\text { Smeđe na vap.-do. }\end{array}$ & 40 & $10-18$ & S-SE & 347 \\
\hline
\end{tabular}

plots. The research area is characterized by two different bedrock types, limestone and flysch, with various soil types (Table 1). The main vegetation type of pine plantations differs among the plots, showing mixtures between eumediterranean - submediterranean and submediterranean mountain vegetation regions, with Quercus pubescens Willd. as a dominant autochthonous species. Average annual rainfall and temperatures across Istria region varies between $842-1571 \mathrm{~mm}$, and $11.6-14.5^{\circ} \mathrm{C}$, respectively. Plots were approximately at the same locations as were the plots of $\mathrm{Di}$ minić et al. (2012) in the previous research. They were square shaped $(20 \times 20 \mathrm{~m})$, measuring $400 \mathrm{~m}^{2}$ each, at different slopes, aspects, elevation and bedrocks. In the center of every plot GPS coordinates were recorded with Ashtech MobileMapper 10. All plots were located in state owned forests at the area of following Forest offices (FO): FO Pazin, Management unit (MU) Motovun (2 plots), MU Planik (3 plots); FO Labin, MU Smokovica (2 plots), FO Opatija-Matulji, MU Liburnija (1 plot), FO Buzet, MU Kras (1 plot).

Macrofungi samples were collected during 2013, from week 36 to week 50, every fortnight. To minimize the effect of mushroom pickers, sampling was conducted on Wednesday and Thursday whenever possible (according to Martínez de Aragón et al. 2007), regardless the weather conditions. By macrofungi we assumed all fungi that form fruit bodies larger than $1 \mathrm{~mm}$, or visible by naked eye, respectively (Arnolds 1992). All samples were recorded with digital camera. Each fungal species with all its sporocarps on the plot represented one sample. They were collected in a wax paper bags, assigned and processed in laboratory on the same day. Sporocarps were counted, measured, described and dried for 48 hours at $35-40{ }^{\circ} \mathrm{C}$. Afterwards, they were packed in plastic bags and deposited to Croatian National Fungarium (CNF) for further identification. Samples that could not be identified only by their macroscopic characteristics, were identified by standard microscopy methods on dry material (Mešić \& Tkalčec 2009), using light microscope Olympus BX51, with magnification up to $1500 \times$ and novel taxonomic literature (Breitenbach \& Kränzlin 1986, 2000; Kuyper 1986; Kytövuori 1989; Bas et al. 1990, 1995, 1999; Sarnari 1998, 2005; Antonín \& Noordeloos 2004, 2010; Knudsen \& Vesterholt 2012). Trophic status of collected fungal species was determined according to Brundrett (2008), Rinaldi et al. (2008) and Comandini et al. (2012). Names of identified species and author abbreviations follow MycoBank (www.mycobank.org 2016).

From each plot one tree with an average crown transparency level was selected to confirm the fungus Spheropsis sapinea presence and to reveal the number of present pycnidia as well. Each tree was represented with five branches and 20 needles (100 needles per plot). Analyzes of Sphaeropsis tip blight infection were conducted in the Laboratory of trees pathology, Faculty of Forestry, University of Zagreb. Needles were kept moistened in Petri dishes for $48 \mathrm{~h}$. Total number of developed pycnidia on needles was counted under a stereo microscope (Leica Leitz MZ8). To confirm the presence of $S$. sapinea, five needles were randomly selected from each sample and analyzed under a light microscope Olympus BX53, with magnification up to $400 \times$, equipped with digital camera Motic MoticamPro 252A. Shape and size of pycnidia and spores were controlled in the cross section (according to Diminić 1997). Crown transparency was 
Table 2: Description of an average number of $S$. sapinea pycnidia $\left(\mathrm{P}_{\mathrm{av}}\right)$, average crown transparency $\left(\mathrm{CT}_{\mathrm{av}}\right)$, species richness $(\mathrm{S})$, ectomycorrhizal $(E C M)$ species richness $\left(S^{\prime}\right)$, Shannon index $(H)$ and ectomycorrhizal $(E C M)$ species Shannon index $\left(H^{\prime}\right)$ at all research plots.

Tablica 2: Prikaz prosječnog broja piknida $S$. sapinea na iglici $\left(\mathrm{P}_{\mathrm{av}}\right)$, prosječne osutosti krošanja $\left(\mathrm{CT}_{\text {av }}\right)$, ukupnog broja vrsta $(\mathrm{S})$, ukupnog broja ektomikoriznih $(E C M)$ vrsta $\left(S^{\prime}\right)$, Shannon indeksa (H) i Shannon indeksa ektomikoriznih (ECM) vrsta $\left(H^{\prime}\right)$ za sve istraživane plohe.

\begin{tabular}{|c|c|c|c|c|c|c|}
\hline Plot - Ploha & $P_{a v}$ & $\mathrm{CT}_{\mathrm{av}}$ & $S$ & $S^{\prime}$ & $\mathrm{H}$ & $\mathrm{H}^{\prime}$ \\
\hline Previž & 0.00 & 8.46 & 26 & 19 & 1.38 & 1.28 \\
\hline Lesišćina & 0.00 & 6.86 & 33 & 22 & 2.54 & 2.14 \\
\hline $\mathrm{Paz}$ & 1.15 & 20.48 & 15 & 7 & 2.17 & 1.30 \\
\hline Mali Golji & 17.73 & 27.50 & 18 & 8 & 1.79 & 1.51 \\
\hline Trstenik & 7.82 & 20.92 & 34 & 14 & 3.04 & 1.98 \\
\hline Ripenda & 13.84 & 17.38 & 25 & 9 & 1.96 & 1.35 \\
\hline Lovranska Draga & 7.11 & 37.60 & 15 & 5 & 2.42 & 1.49 \\
\hline Trošti & 24.46 & 44.17 & 35 & 9 & 2.84 & 1.33 \\
\hline Kurbino brdo & 22.21 & 27.31 & 31 & 7 & 2.35 & 0.60 \\
\hline
\end{tabular}

assessed for all trees on plots according to ICP Forest methodology (Eichhorn 2010; Potočić \& Seletković 2011).

Fungal diversity was evaluated using Shannon diversity in$\operatorname{dex}(H)$ (Heip et al. 1998; Molles 1999; Martín-Pinto et al. 2006), defined as:

$$
(H)=-\sum_{i=1}^{S} P_{i}\left(\ln P_{i}\right)
$$

where $P_{i}$ stands as a proportion $(n / N)$ of individuals in a single species $(n)$, divided by the total number $(N)$ of individuals in the sample, while $S$ represents the total number of recorded species (species richness) at the plot.

Shannon index was calculated with PAST 3.06 software (Paleontological Statistics, Natural History Museum, University of Oslo, Norway), based on the total number of species $(H)$ and number of ectomycorrhizal species $\left(H^{\prime}\right)$ separately for every plot. Species richness $(S)$ and Shannon index $(H)$ were used as independent variables, while the number of $S$. sapinea pycnidia and crown transparency were used as dependent variables to calculate linear regression and correlation analyzes to compare the values between the plots. All analyzes were performed with Statistica 10 software (StatSoft, Inc., Tulsa, OK, USA). To test statistical significance, in all analyzes a 95\% confidence level was used $(\mathrm{p}<0.05)$. Statistical results were interpreted according to Horvat \& Ivezić (2005).

\section{RESULTS}

\section{REZULTATI}

Results from data obtained on nine plots during 2013 showed different species richness, crown transparency and diversity index distribution. In total, 3377 sporocarps were recorded, belonging to 124 fungal species and 48 genera, with 51 ectomycorrhizal (ECM) species. Plot Trošti was the most rich in fungi species (35), and was followed by plots Trstenik (34) and Lesišćina (33) (Table 2). At plots Lovranska Draga and Paz richness accounted for only 15 species.
The highest number of ECM species was recorded on plots Lesišćina (22), and Previž (19), while the plot Lovranska Draga was the most poor in ECM species (5). The highest value of Shannon index $(H)$ was recorded on plot Trstenik (3.04), while the lowest one was at plot Previž (1.38) (Table 2). For ECM species, the highest value of Shannon index $\left(H^{\prime}\right)$ was at plot Lesišćina (2.14), while the lowest one was at plot Kurbino brdo (0.60). Sphaeropsis sapinea pycnidia were not found at plots Previž and Lesišćina, while they were abundant at plots Trošti, Kurbino brdo and Mali Golji. On analyzed needles, together with S. sapinea, Truncatella hartigii (Tubeuf) Steyaert was present. Plot Trošti was the most infected by S. sapinea with an average number of 24.46 pycnidia/needle (Table 2), and had the highest average crown transparency (44.17\%), while the lowest one was recorded on plot Lesišćina (6.86\%) (Table 2).

According to the linear regression model, there is an indication of weak positive correlation ( $r=0.273)$, between species richness and an average number of S. sapinea pycnidia, but it is not statistically significant $(\mathrm{p}=0.477)$ (Figure 1$)$.

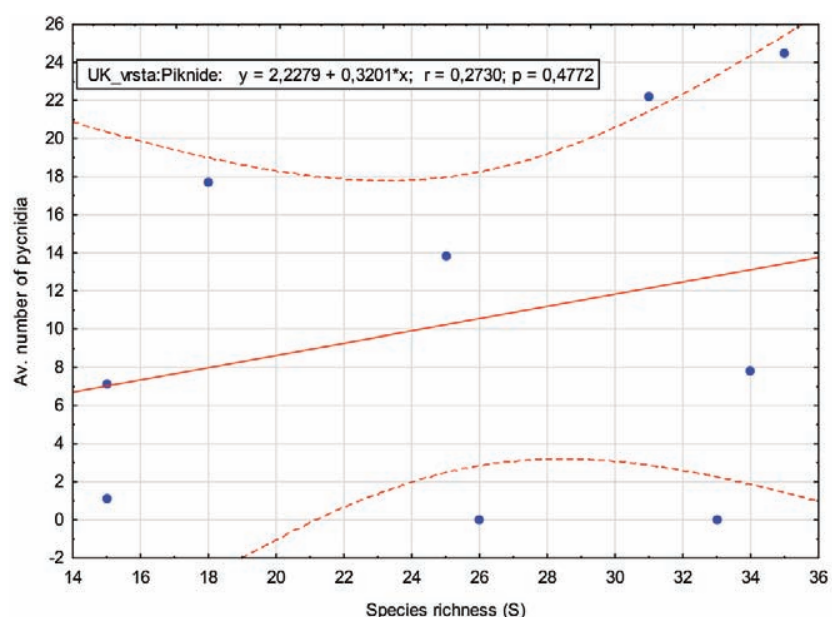

Figure 1: Correlation of an average number of $S$. sapinea pycnidia on needle towards species richness (S) with 95\% confidence interval.

Slika 1: Odnos prosječnog broja piknida $S$. sapinea na iglici prema ukupnom broju vrsta (S) s 95\% intervalom pouzdanosti. 


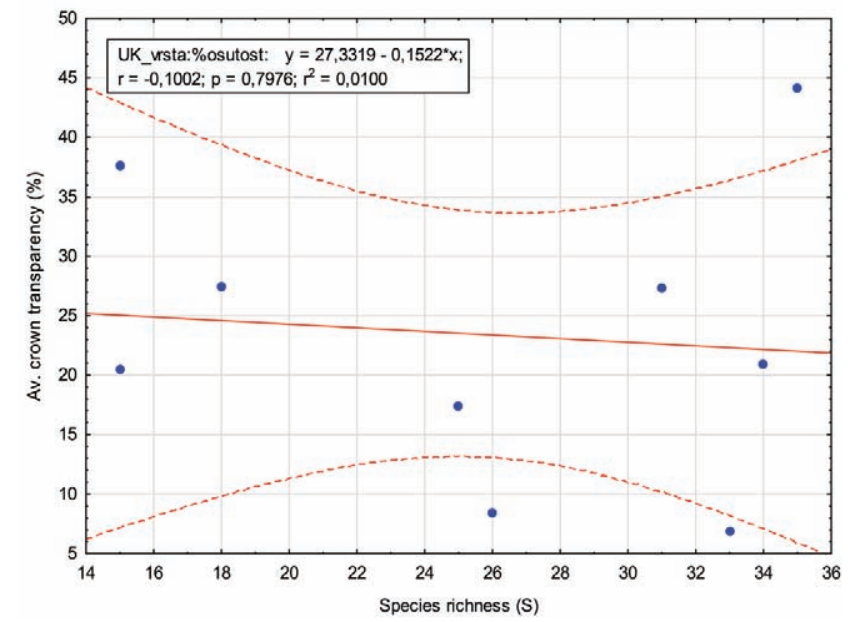

Figure 2: Correlation of an average crown transparency (\%) towards species richness (S) with $95 \%$ confidence interval.

Slika 2: Odnos prosječne osutosti krošanja (\%) prema ukupnom broju vrsta (S) s $95 \%$ intervalom pouzdanosti.

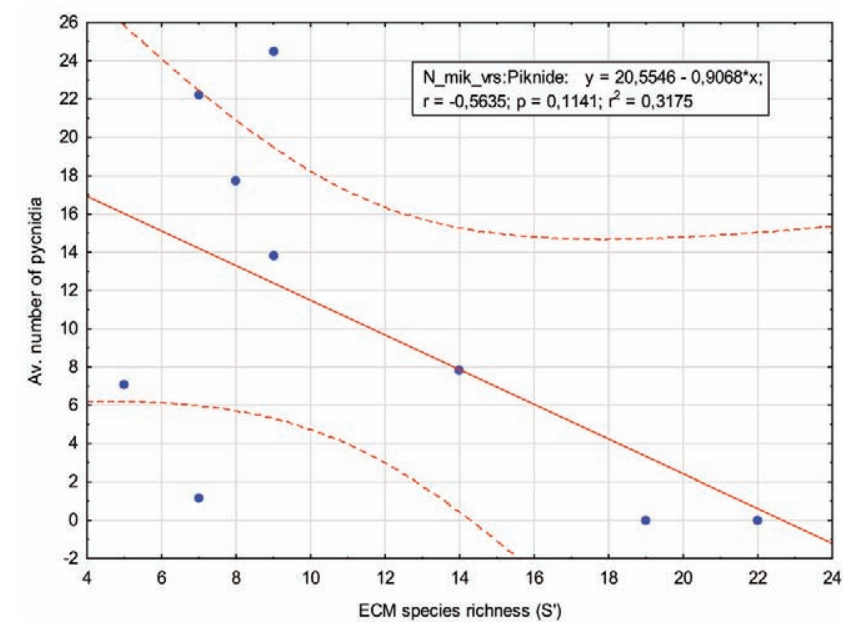

Figure 3: Correlation of an average number of $S$. sapinea pycnidia on needle towards ECM species richness ( $S^{\prime}$ ) with $95 \%$ confidence interval. Slika 3: Odnos prosječnog broja piknida $S$. sapinea na iglici prema ukupnom broju ECM vrsta (S') s 95\% intervalom pouzdanosti.

Species richness does not correlate with crown transparency $(\mathrm{r}=-0.100)$ (Figure 2). ECM species richness seemingly negatively correlates $(r=-0.564)$ with an average number of pycnidia on needle, but it is also not statisticaly significant $(\mathrm{p}=0.114)$ (Figure 3$)$. ECM species richness showed statisticaly significant $(\mathrm{p}=0.018)$, and very strong negative correlation $(\mathrm{r}=-0.756)$ in respect to an average crown transparency (Figure 4). Between Shannon index and an average number of pycnidia on needle (Figure 5), there is an indication of very weak positive correlation $(\mathrm{r}=0.241)$, albeit again not statistically significant $(\mathrm{p}=0.532)$. Similar results were obtained for correlation between Shannon index and an average crown transparency which is positive $(\mathrm{r}=0.425)$, but not statistically significant $(\mathrm{p}=0.254)(\mathrm{Fi}-$ gure 6). On the other hand, ECM species Shannon index

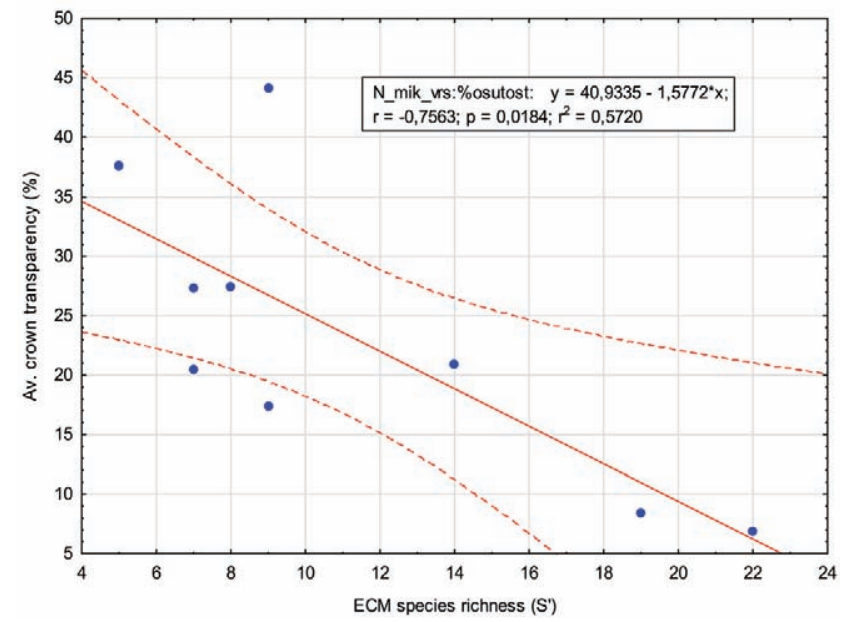

Figure 4: Correlation of an average crown transparency (\%) towards ECM species richness $\left(S^{\prime}\right)$ with $95 \%$ confidence interval.

Slika 4: Odnos prosječne osutosti krošanja (\%) prema ukupnom broju ECM vrsta (S') s 95\% intervalom pouzdanosti.

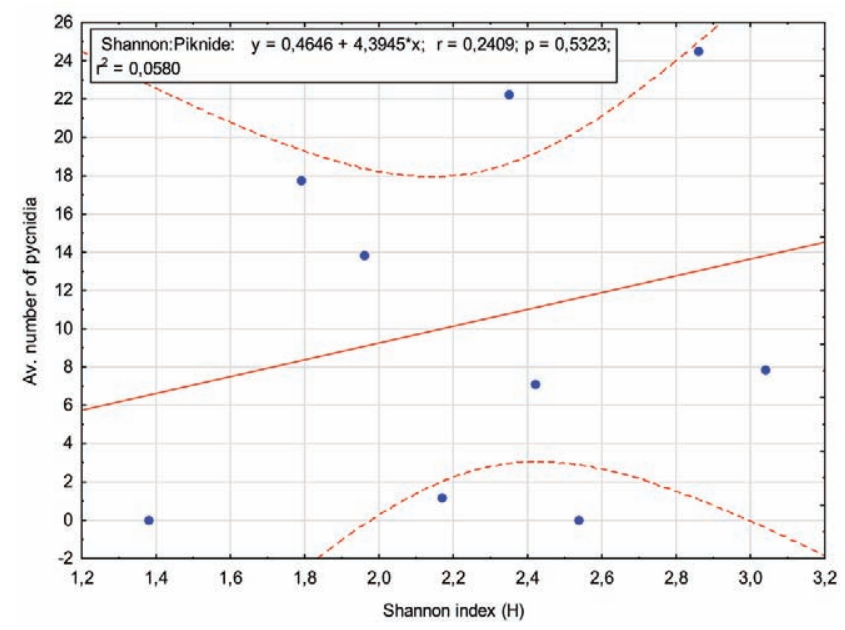

Figure 5: Correlation of an average number of $S$. sapinea pycnidia on needle towards Shannon index $(\mathrm{H})$ with $95 \%$ confidence interval.

Slika 5: Odnos prosječnog broja piknida $S$. sapinea na iglici prema Shannon indeksu (H) s 95\% intervalom pouzdanosti.

indicated strong negative correlation $(\mathrm{r}=-0.511 ; \mathrm{p}=0.160)$ with respect to an average number of pycnidia, but also not statistically significant (Figure 7). Even weaker correlation, and again not statistically significant $(r=-0.325 ; p=0.393)$, was found between ECM species Shannon index and an average crown transparency (Figure 8).

\section{DISCUSSION AND CONCLUSION RASPRAVA I ZAKLJUČAK}

Ecological and economical losses in Austrian pine plantations caused by Sphaeropsis sapinea keeps preoccupying forest managers and scientists attempting to prevent and minimize its damage. Our study was based on sporocarp sampling which is a very complex method, time consuming 


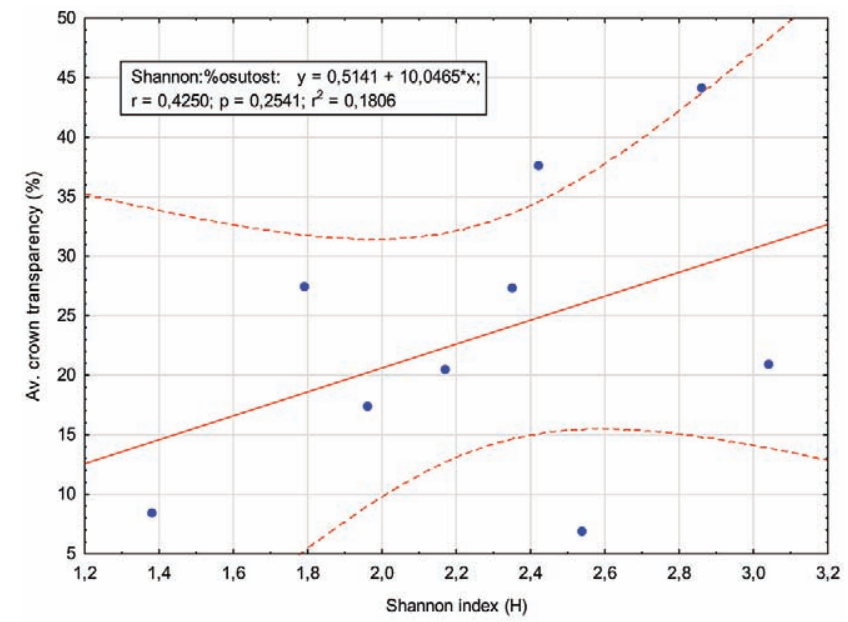

Figure 6: Correlation of an average crown transparency (\%) towards Shannon index $(\mathrm{H})$ with $95 \%$ confidence interval.

Slika 6: Odnos prosječne osutosti krošanja (\%) prema Shannon indeksu (H) s $95 \%$ intervalom pouzdanosti.

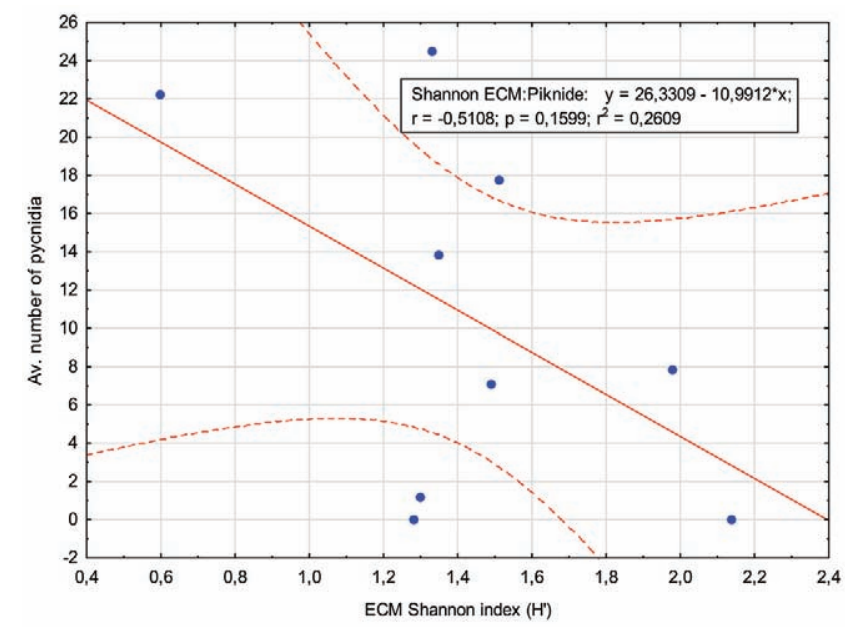

Figure 7: Correlation of an average number of $S$. sapinea pycnidia on needle towards ECM species Shannon index $\left(\mathrm{H}^{\prime}\right)$ with $95 \%$ confidence interval.

Slika 7: Odnos prosječnog broja piknida S. sapinea na iglici prema Shannon indeksu ECM vrsta (H') s 95\% intervalom pouzdanosti.

and a topic of many debates (Zotti et al. 2013). At the same time, it is cheaper than molecular methods, with epigeous fungal sporocarps easily accessible in favorable conditions (Schmit \& Lodge 2005). Macrofungi emphasize a vast majority of ectomycorrhizal and saprobic species which showed repeated positive correlation with mycelial activity (Kuyper 1994), which justifies the selected methodology. Described results in this paper are a part of the research process that continues on previous studies of the same Austrian pine plots where predisposition to $S$. sapinea infections caused by draught was determined as a key factor (Diminić 1997; Diminić et al. 2003, 2012). Furthermore, Zgrablić et al. (2015) confirmed the importance of ectomycorrhizal (ECM) fungi ratio in the total count of species.

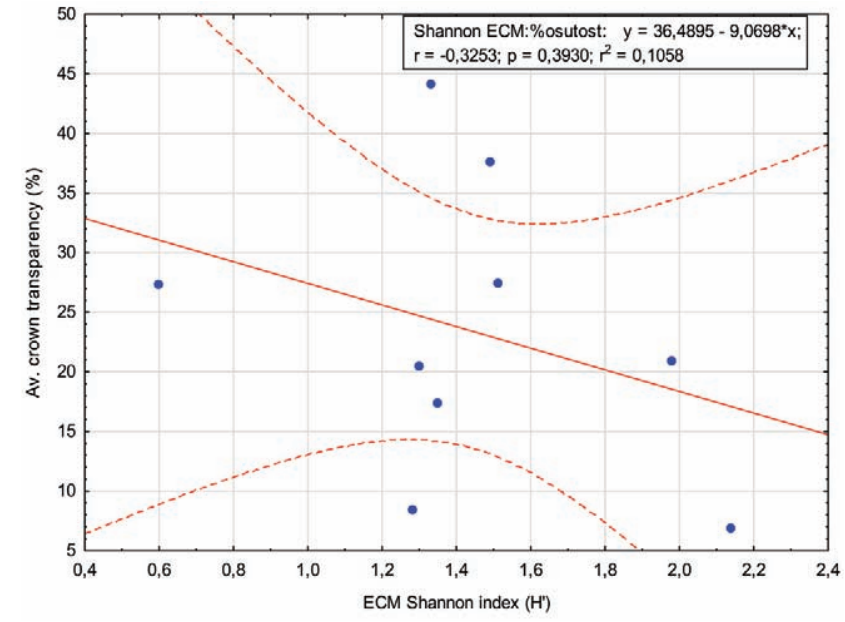

Figure 8: Correlation of an average crown transparency (\%) towards ECM species Shannon index $\left(\mathrm{H}^{\prime}\right)$ with $95 \%$ confidence interval.

Slika 8: Odnos prosječne osutosti krošanja (\%) prema Shannon indeksu ECM vrsta $\left(\mathrm{H}^{\prime}\right)$ s $95 \%$ intervalom pouzdanosti.

Plantation with a ratio of EMC fungal species higher than $60 \%$ was free from S. sapinea pycnidia on needles and had a negligible crown transparency. It is difficult to compare our results with other studies because there is a gap of knowledge considering the research of fungi in Austrian pine forests and plantations in general, especially in relation to health conditions. Recorded 124 fungal species, of which 51 were ECM in our study, represent higher species richness than has been recorded in Austrian pine plantations on serpentine bedrock in Liguria, Italy (Zotti et al. 2013). There were 94 species recorded of which 47 ECM. Shannon diversity index ranged from 1.84-3.34 for total species richness, and 1.05-2.26 for ECM species group, reflecting higher values than in our study. However, it is difficult to compare these studies because of different methodology. Experiment in Liguria consisted of 11 plots which were larger $(32 \times 32 \mathrm{~m})$ and surveyed through four years for epigeous and hypogeous fungi, but without considering the health status of Austrian pine trees. Research of Austrian pine macrofungi in Istria at previous study (Zgrablić et al. 2015) revealed a total of 88 epigeous fungal species of which 47 were ECM. Luoma \& Eberhart (2006) conducted a research of the below-ground ECM diversity in the Pacific Northwest, USA, on Douglas fir affected by Swiss needle cast disease (SNC) (Phaeocryptopus gaeumannii (T. Rohde) Petr.). According to their preliminary results, it is evident that stands with stronger SNC severity had a significantly less ECM types/soil core than stands with low infection rate and the control site outside the SNC disease symptoms zone. They conclude that below-ground ECM community could be used as a forest health indicator for early detection of Swiss needle cast (SNC) susceptibility.

Many studies clearly indicated the effect of air pollution on forest ecosystems, consequently showing a decline in num- 
ber of ECM fungal species, their sporocarps and mycorrhizal root tips (Termorshuizen \& Schaffers 1987, 1989; Arnolds 1991; Fellner 1993; Fellner \& Pešková 1995; Matočec et al. 2000; Pešková 2005, 2007; Kraigher et al. 2007). Together with loss of mycorrhizal diversity, symptoms of disturbance were visible on many forest tree species, especially conifers. Even though it is believed that fungi play an important role in stability of forest ecosystems and help protect their plant host from physiological stress and pathogen, published results until now did not clearly prove it (Egli 2011). From this point of view, saprobic and ECM macrofungi cannot be generalized as indicators of forest trees health status. To consider them as forest health indicators it is necessary to study more in detail the specific group of macrofungi and their relation towards the different abiotic and biotic factors.

Based on the results of this study, we partly rejected our hypothesis. We concluded that total species richness $(S)$ cannot be used as an indicator of forest susceptibility to S. sapinea disease outbreak due to week or nonexistent correlation with pycnidia and crown transparency (Figure $1 \& 2)$. The same statement can be applied for Shannon index $(H)$ as an indicator of $S$. sapinea pycnidia (Figure 5). ECM species richness $\left(S^{\prime}\right)$ showed an opposite trend. With its increase to 22 species/plot the number of S. sapinea pycnidia decreases to zero, which is confirmed by the regression model, although not statistically significant ( $\mathrm{Fi}$ gure 3). Even more, there is a strong negative and statistically significant correlation between $S$ ' and crown transparency (Figure 4). With 20 species/plot, we can expect the crown transparency to be below $10 \%$. In this case, we can assume the ECM species diversity as a good indicator of Austrian pine plantations health status. Nevertheless, the crown transparency itself does not indicate the presence of $S$. sapinea and can be used only in the case when the pathogen is confirmed. According to linear regression model, we can expect crown transparency higher than $25 \%$ when $H$ is 2.4 , and higher than $30 \%$ when $H$ is above 3.0 (Figure 6). The correlation between $H^{\prime}$ and crown transparency is week and consequently rejected our hypothesis, but there is a strong correlation between $H^{\prime}$ and the number of $S$. sapinea pycnidia. In the case when $H^{\prime}$ surpasses 2.4 we can expect the healthy needles without $S$. sapinea pycnidia presence, which in a part, confirms our assumption. To gain more reliable and precise results, it is recommended to survey additional plots through longer period and to include in research analyses of stand factors like altitude, aspect, precipitations, bedrock and soil type, $\mathrm{pH}$, plant nutrition status and phytocoenological survey. That would enable the development of new methods and models of integrated forest protection in accordance with pronounced changes of ecological conditions of the Austrian pine habitats.

\section{ACKNOWLEDGMENTS}

\section{ZAHVALA}

This research was co-founded by the Croatian Ministry of Science, Education and Sport in the frame of projects ' $\mathrm{Fo}$ rests' growth and development in changed ecological and management conditions' (024-0242049-2106) and 'Biotic agents associated with forest tree decline in Croatian Karst' (0680681966-2775), and by the Istria County, Department for Agriculture, Forestry, Hunting, Fisheries and Water Management. We cordially thank Zdenko Tkalčec, Ph.D. and Armin Mešić, Ph.D., Ruđer Bošković Institute, for great help in fungal identification. We thank to the employees of Croatian Forest Research Institute, Center for Forest Ecosystems Goods and Services 'Josip Ressel', Josip Čulinović, Anton Brenko and Ana Fornažar, for their help during the collecting and processing of fungal samples. For helping with processing the samples of Sphaeropsis sapinea at Faculty of Forestry, University of Zagreb, we thank to Marno Milotić, Jelena Kranjec and Leopold Cvetan. We also wish to thank the employees of Croatian Forests L.t.d., Forest office in Labin, for helping us to set up the research plots. For the meteorological data we tank to the Croatian Meteorological and Hydrological Service.

\section{REFERENCES \\ LITERATURA}

- Antonín, V., M. E. Noordeloos, 2004: A monograph of the genera Hemimycena, Delicatula, Fayodia, Gamundia, Myxomphalia, Resinomycena, Rickenella and Xeromphalina (Tribus Mycenae sensu Singer, Mycena excluded) in Europe. IHW Verlag, Eching, 1-279.

- Antonín, V., M. E. Noordeloos, 2010: A monograph of marasmioid and collybioid fungi in Europe. IHW-Verlag, Eching, $1-478$.

- Arnolds, E., 1991: Decline of ectomycorrhizal fungi in Europe. Agr Ecosyst Environ, 35: 209-244.

- Arnolds, E., 1992: The analysis and classification of fungal communities with special reference to macrofungi. In: Winterhoff, W., (ed.), Fungi in vegetation science. Kluwer Academic Publishers, Dordrecht, pp. 7-47.

- Bas, C., T. W. Kuyper, M. E. Noordeloos, E. C. Vellinga, (ed.), 1990: Flora agaricina neerlandica. 2. A. A. Balkema, Rotterdam, Brookfield, pp. 1-137.

- Bas, C., T. W. Kuyper, M. E. Noordeloos, E. C. Vellinga, (ed.), 1995: Flora agaricina neerlandica. 3. A. A. Balkema, Rotterdam, Brookfield, pp. 1-183.

- Bas, C., T. W. Kuyper, M. E. Noordeloos, E. C. Vellinga, (ed.), 1999: Flora agaricina neerlandica. 4. A. A. Balkema, Rotterdam - Brookfield, pp. 1-191.

- Blackwell, M., 2011: The fungi: 1, 2, 3 .. 5.1 million species? American Journal of Botany 98(3): 426-438.

- Breitenbach, J., F. Kränzlin, 1986: Fungi of Switzerland. Volume 2: Non-Gilled Fungi. Luzern, Switzerland, Verlag Mykologia, pp. 1-412. 
- Breitenbach, J., F. Kränzlin, 2000: Fungi of Switzerland. 5. Mykologia Luzern, Luzern, pp. 1-338.

- Brundrett, M. C., 2008: Ectomycorrhizas. In: Mycorrhizal Associations: The Web Resource. Version 2.0. Accessed: 16. 01. 2016. http://mycorrhizas.info/ecm.html.

- Comandini, O., A. C. Rinaldi, T. W. Kuyper, 2012: Measuring and estimating ectomycorrhizal fungal diversity: a continuous challenge. In: Pagano, M., (ed.), Mycorrhiza: occurrence in natural and restored environments. Nova Science Publishers. Nueva York, pp. 165-200.

- Deriu, L., 2010: Selezione di funghi endofiti antagonisti di patogeni forestali. Tesi di Dottorato di Ricerca in: Monitoraggio e Controllo degli Ecosistemi Forestali in Ambiente Mediterraneo, Università degli Studi di Sassari, pp. 1-76.

- Diminić, D., 1997: Istraživanje gljive Sphaeropsis sapinea (Fr.) Dyko et Sutton na borovima u Hrvatskoj. Doctoral thesis, University of Zagreb, Faculty of Forestry, pp. 1-170.

- Diminić, D., B. Hrašovec, N. Potočić, 2003: The contributing role of $\mathrm{SO}_{2}$ and drought in forest decline of Austrian pine in coastal Croatia. Ekol Bratislava, 22(Suppl. 1): 80-83.

- Diminić, D., N. Potočić, I. Seletković, 2012: Uloga staništa u predispoziciji crnoga bora (Pinus nigra Arnold) na zarazu fitopatogenom gljivom Sphaeropsis sapinea (Fr.) Dyko et Sutton u Istri. Sumar list, 136(1-2): 19-36.

- Druebert, C., C. Lang, K. Valtanen, A. Polle, 2009: Beech carbon productivity as driver of ectomycorrhizal abundance and diversity. Plant Cell Environ, 32: 992-1003.

- Egli, S., 2011: Mycorrhizal mushrooms diversity and productivity - an indicator of forest health? Ann For Sci, 68: 81-88.

- Eichhorn, J., P. Roskams, M. Ferretti, V. Mues, A. Szepesi, D. Durrant, 2010: Visual Assessment of Crown Condition and Damaging Agents. Manual Part IV. In: Manual on methods and criteria for harmonized sampling, assessment, monitoring and analysis of the effects of air pollution on forests. UNECE ICP Forests Programme Coordinating Centre, Hamburg, pp. 1-49. ISBN: 9783-926301-03-1. [http://www.icp-forests.org/Manual.htm]

- Feldmann, F., I. Hutter, C. Grotkass, 2003: Mycorrhizal fungi as factors of integrated plant protection in urban horticulture: the state of the art. Mitt. d. Biol. Bundesanstalt für Land- und Forstwirtschaft, 394: 205-211.

- Fellner, R., 1989: Mycorrhiza-forming fungi as bioindicators of air pollution. Agaric Ecosystems Environ, 28: 115-120.

- Fellner, R., 1993: Air pollution and mycorrhizal fungi in central Europe. In: Pegler, D. N., Boddy, L., Ing, B., Kirk, P. M., (ed.), Fungi of Europe: Investigation, Recording and Conservation. Royal Botanic Gardens, Kew, pp. 239-250.

- Fellner, R., V. Pešková, 1995: Effects of industrial pollutants on ectomycorrhizal relationships in temperate forests. Can J Bot, 73(Suppl. 1): 1310-1315.

- Heip, C. H. R., P. M. J. Herman, K. Soetaert, 1998: Indices of diversity and evenness. Oceanis, 24(4): 61-87.

- Holuša, J., V. Pešková, L. Vostrá, M. Pernek, 2009: Impact of mycorrhizal inoculation on spruce seedling: comparisons of a 5 -year experiment in forests infested by honey fungus. Period biol, 111(4): 413-417.

- Horvat, D., M. Ivezić, 2005: Biometrika u poljoprivredi. Poljoprivredni fakultet Osijek, pp. 1-460.

- Kendrick, B., 2000: The fifth kingdom, Third edition. Focus Publishing, R. Pullins Co., Newburyport, pp. 1-373.
- Knudsen, H., J. Vesterholt, 2012: Funga Nordica: agaricoid, boletoid and cyphelloid genera. Nordsvamp, Copenhagen, pp. 1-1083.

- Kraigher, H., S. A. S. Petkovšek, T. Grebenc, P. Simončič, 2007: Types of ectomycorrhiza as pollution stress indicators: case studies in Slovenia. Environ monit assess, 128(1-3): 31-45.

- Kuyper, T. W., 1986: A revision of the genus Inocybe in Europe. I. Subgenus Inosperma and the smooth-spored species of subgenus Inocybe. - Persoonia, Suppl. 3. Rijksherbarium, Leiden, pp. 1-247.

- Kuyper, T. W., 1994: Fungal species diversity and forest ecosystem functioning in The Netherlands. In: Boyle, T.J. B., Boyie, C. E. B., (ed.), Biodiversity, Temperate Ecosystems, and Global Change. Springer, Berlin Heidelberg, pp. 99-122.

- Kuyper, T. W., K. E Giller, 2011: Biodiversity and ecosystem functioning below-ground. Agrobiodiversity Management for Food Security-a critical review. CABI, Oxfordshire, pp. 134-149.

- Kytövuori, I., 1989: The Tricholoma caligatum group in Europe and North Africa. Karstenia, 28: 65-77.

- Luoma, D. L., J. L. Eberhart, 2006: Are differences in the ectomycorhhiza community correlated with swiss needle cast severity? In: Shaw, D., (ed.), Swiss needle cast cooperative, Annual report, Oregon State University, Corvallis, pp. 60-64.

- Martín-Pinto, P., H. Vaquerizo, F. Peñalver, J. Olaizola, J. A. Oriade-Rueda, 2006: Early effects of a wildfire on the diversity and production of fungal communities in Mediterranean vegetation types dominated by Cistus ladanifer and Pinus pinaster in Spain. For Ecol Manag, 225(1): 296-305.

- Martínez de Aragón, J., J. A. Bonet, C. R. Fischer, C. Colinas, 2007: Productivity of ectomycorrhizal and selected edible saprotrophic fungi in pine forests of the pre Pyrenees Montains, Spain: Predictive equations for forest management of mycological resources. For Ecol Manag, 252: 239-256.

- Matočec, N., O. Antonić, D. Mrvoš, A. Piltaver, D. Hatić, D. Bukovec, 2000: An estimate of fir forest health based on mycobioindication: the Križ stream catchment area, Gorski Kotar, Croatia, a case study. Nat Croat, 9(1): 15-33.

- Mešić, A., Z. Tkalčec, 2009: Studies on Croatian Basidiomycota 1: Gerhardtia piperata (Agaricales). Mycotaxon, 110: 413-421.

- Molles, M. C. Jr., 1999: Ecology: concepts and applications, $1^{\text {st }}$ edition. WCB McGrow-Hill, Boston, pp. 1-482.

- Montecchio, L., E. Motta, S. Mutto Accordi, 2009: Le ectomicorrize come indicatori di salute delle piante forestali. Atti del Terzo Congresso Nazionale di Selvicoltura. Taormina (ME). Accademia Italiana di Scienze Forestali, Firenze, pp. 657-662.

- MycoBank, 2016: Internazional Mycological Association. Accessed: 19. 01. 2016. http://www.mycobank.org/BioloMICS.as px?Link $=$ T\&TableKey $=14682616000000067 \&$ Rec $=25932 \&$ Fie lds $=$ All

- Palermo, B. L., K. M. Clancy, G. W. Koch, 2003: The potential role of ectomycorrhizal fungi in determining Douglas-fir resistance to defoliation by the Western Spruce Budworm (Lepidoptera: Torticidae). J Econ Entomol, 96(3): 783-791.

- Perini, C., A. Laganà, 2004: Conservation and value of fungal diversity in the Mediterranean area: an overview of Tuscan experience. Mycol Balc, 1: 25-29.

- Pernek, M., S. Novak Agbaba, N. Lacković, N. Đođ, I. Lukić, S. Wirth, 2012: Uloga biotičkih čimbenika u sušenju borova $(P i-$ nus spp.) na području sjeverne Dalmacije. Sumar list, 136(5-6): 343-354. 
- Perotto, S., P. Angelini, V. Bianciotto, P. Bonfante, M. Girlanda, T. Kull, A. Mello, L. Pecoraro, C. Perini, A. M. Persiani, A. Saitta, S. Sarrocco, G. Vannacci, R. Venanzoni, G. Venturella, M. A. Selosse, 2013: Interactions of fungi with other organisms. Plant Biosyst - An International Journal Dealing with all Aspects of Plant Biology: Official Journal of the Societa Botanica Italiana, 147(1): 208-218. DOI:10.1080/11263504.2012.753136

- Pešková, V., 2005: Dynamics of oak mycorrhizas. J For Sci, 51: 259-267.

- Pešková, V., 2007: Changes in the mycorrhizal status of some mountain spruce forests. J For Sci, 53(Special Issue): 82-89.

- Potočić, N., I. Seletković, 2011: Osutost šumskog drveća u Hrvatskoj u razdoblju od 2006. do 2009. godine. Sumar list, 135(13): 149-158.

- Rinaldi, A. C., O. Comandini, T. W. Kuyper, 2008: Ectomycorrhizal fungal diversity: separating the wheat from the chaff. Fungal Divers, 33: 1-45.

- Sarnari, M., 1998: Monografia illustrata del Genere Russula in Europa. Tomo Primo. A.M.B., Trento - Vicenza, pp. 1-799.

- Sarnari, M., 2005: Monografia illustrata del Genere Russula in Europa. Tomo Secondo. A.M.B., Trento - Vicenza, pp. 1-768.

- Scattolin, L., E. Dal Maso, S. Mutto Accordi, L. Sella, L. Montecchio, 2012: Detecting asymptomatic ink-diseased chestnut trees by the composition of ectomycorrhizal community. For Path, 42: 501-509.

- Schmit, J. P., D. J. Lodge, 2005: Classical methods and modern analysis for studying fungal diversity. In: Dighton, J., White, J. F., Oudemans, P.,(ed.), The Fungal Community: its organization and role in the ecosystem, $3^{\text {rd }}$ Edition, CRC Press, pp. 193-214.
- Stanosz, G. R., J. T. Blodgett, D. R. Smith, E. L. Kruger, 2001: Water stress and Sphaeropsis sapinea as a latent pathogen of red pine seedlings. New Phytol, 149(3): 531-538.

- Swart W. J., M. J. Wingfield 1991: Biology and control of Sphaeropsis sapinea on Pinus species in South Africa. Plant Dis, 75: 761-766.

- Termorshuizen, A. J., A. P. Schaffers, 1987: Occurrence of carpophores of ectomycorrhizal fungi in selected stands of Pinus sylvestris in the Netherlands in relation to stand vitality and air pollution. Plant Soil, 104: 209-217.

- Termorshuizen, A. J., A. P. Schaffers, 1989: The relation in the field between fruitbodies of mycorrhizal fungi and their mycorrhizas. Agr Ecosyst Environ, 28(1): 509-512.

- Tkalčec, Z., A. Mešić, N. Matočec, I. Kušan, 2008: Crvena knjiga gljiva Hrvatske. Ministarstvo kulture, Državni zavod za zaštitu prirode, Zagreb, pp. 1-428.

- Zgrablić, Ž., Z. Tkalčec, A. Mešić, H. Marjanović, D. Diminić, 2015: Do ectomycorrhizal fungi reduce Austrian pine (Pinus nigra J. F. Arnold) susceptibility to Sphaeropsis sapinea (Fr.) Dyko et Sutton infection? Sumar list, 139(7-8): 329-337.

- Zgrablić, Ž., A. Brenko, N. Matočec, I. Kušan, A. Fornažar, J. Čulinović, G. Prekalj, 2014: Strategija održivog razvoja tartufarstva u Istarskoj županiji. Istarska županija, Upravni odjel za poljoprivredu, šumarstvo, lovstvo, ribarstvo i vodoprivredu, Pazin, pp. 1-64.

- Zotti, M., S. Di Piazza, E. Ambrosio, M. G. Mariotti, E. Roccotiello, A. Vizzini, 2013: Macrofungal diversity in Pinus nigra plantations in Northwest Italy (Liguria). Sydowia, 65(2): 223243.

\section{Sažetak}

Patogena gljiva Sphaeropsis sapinea (Fr.) Dyko et Sutton uzrokovala je značajna sušenja kultura crnoga bora (Pinus nigra J. F. Arnold) u Istri tijekom posljednja tri desetljeća. Iako je sam patogen detaljno istraživan $\mathrm{u}$ Hrvatskoj, ali i mnogim drugim zemljama, još uvijek nisu poznati svi čimbenici koju sudjeluju u izbijanju i širenju zaraza. Stres uzrokovan nedostatkom vode opisan je kao jedan od najvažnijih čimbenika koji stvara predispoziciju borova na zarazu sa S. sapinea. No, novija istraživanja pokazuju da značajnu ulogu u osjetljivosti crnoga bora na zarazu imaju i ektomikorizne (ECM) gljive. Gljive su vrlo značajan čimbenik stabilnosti šumskih ekosustava, bez obzira kojoj trofičkoj grupi pripadaju. S obzirom na opću slabu istraženost makrogljiva, posebno njihove bioraznolikosti i funkcionalne važnosti pojedinih vrsta u ekosustavima, cilj ovoga istraživanja bio je utvrditi bogatstvo vrsta gljiva i indeks njihove raznolikosti. Postavljena je hipoteza da kulture crnoga bora s većim bogatstvom vrsta i većim indeksom raznolikosti pokazuju manju osjetljivost prema napadu S. sapinea. Hipoteza je nadalje razdijeljena između ukupnog bogatstva vrsta i Shannon indeksa raznolikosti te bogatstva ECM vrsta i pripadajućeg Shannon indeksa.

Istraživanje se baziralo na sakupljanju nadzemnih plodišta makrogljiva (većih od $1 \mathrm{~mm}$ ). Uzorci gljiva sakupljani su tijekom 2013. godine na devet trajnih ploha od 36. do 50. tjedna u godini. Sve plohe nalazile su se državnim šumama na području UŠP Buzet (Tablica 1). Svi uzorci pohranjeni su u Hrvatski nacionalni fungarij (CNF). Vrste su određivane standardnim metodama mikroskopiranja. Osutost krošanja svih stabala na plohama određena je prema ICP Forest metodi. Na svakoj je plohi analizirano po jedno stablo crnoga bora s prosječnom osutošću krošnje, kako bi se utvrdila prisutnost i brojnost piknida S. sapinea na iglicama. Za statističku analizu podataka korišteni su programi Statistica 10 (StatSoft, Inc., Tulsa, OK, USA) i PAST 3.06 (Paleontological Statistics, Natural History Museum, University of Oslo, Norway).

Istraživanjem je obrađeno ukupno 3377 plodišta makrogljiva. Određene su 124 vrste, od kojih je 51 bila ektomikorizna (ECM). Najviše vrsta (S) zabilježeno je na plohi Trošti (35), a najmanje na plohama Paz i Lovranska Draga (15) (Tablica 2). Najveće bogatstvo ECM vrsta ( $S^{\prime}$ ) zabilježeno je na plohi Lesišćina (22), dok ih je najmanje bilo na plohi Lovranska Draga (5). Najviša vrijednost Shannon indeksa $(H)$ zabilježena je na plohi 
Trstenik (3,04), a najmanja na plohi Previž $(1,38)$ (Tablica 2). Najviši Shannon indeks ECM vrsta $\left(H^{\prime}\right)$ zabilježen je na plohi Lesišćina $(2,14)$, a najniži na plohi Kurbino brdo $(0,60)$. Na plohi trošti utvrđen je najveći prosječan broj piknida S. sapinea po iglici $(24,46)$ te najviša prosječna osutost krošanja $(44,17$ \%) (Tablica 2$)$. Na plohama Previž i Lesišćina nije utvrđena prisutnost piknida S. sapinea na iglicama, a ploha Lesišćina imala je i najmanju prosječnu osutost krošanja (6,86 \%). Koeficijent korelacije pokazuje slabu i statistički neznačajnu povezanost bogatstva vrsta s brojem piknida S. sapinea na iglici $(r=0,273)$ (Slika 1), dok s prosječnom osutošću krošanja nema povezanosti $(\mathrm{r}=0,100)$ (Slika 2). Povezanost bogatstva ECM vrsta pokazuje jaku negativnu korelaciju s brojem piknida $(r=-0,564)$ (Slika 3), te vrlo jaku negativnu korelaciju $(r=-0,756)$ s osutošću krošanja (Slika 4). Shannon indeks pokazuje statistički neznačajnu i jako slabu korelaciju s prosječnim brojem piknida $(r=0,241)$ (Slika 5) te srednje jaku povezanost s osutošću krošanja $(r=0,425)$ (Slika 6). Shannon indeks ECM vrsta pokazuje jaku negativnu povezanost s brojem piknida $(r=-0,511)$ (Slika 7$)$ te slabu negativnu povezanost s osutošću krošanja $(r=-0,325)$ (Slika 8).

Ovaj rad dio je kontinuiranog procesa istraživanja šteta koje pričinjava $S$. sapinea i nastavak je prijašnjih istraživanja predispozicije crnoga bora na zarazu ovim patogenom u Istri, prilikom kojih je utvrđen utjecaj staništa, stresa i ektomikoriznih gljiva na zarazu. S obzirom na dobivene rezultate, odbacujemo hipotezu da ukupno bogatstvo vrsta može poslužiti kao pouzdan biološki pokazatelj osjetljivosti crnoga bora na zarazu sa S. sapinea i osutosti krošanja zbog vrlo slabe ili nepostojeće veze između promatranih varijabli. Pripadajući Shannon indeks raznolikosti vrlo je slabo povezan s brojem piknida na iglici, pa je stoga također odbačen kako pouzdan indikator zaraze. Shannon indeks ECM vrsta slabo je povezan s osutošću te također ne može poslužiti kao pouzdan pokazatelj zdravstvenoga stanja istraživanih kultura crnoga bora. Nasuprot tomu, bogatstvo ECM vrsta može poslužiti kao dobar pokazatelj prisutnosti piknida i osutosti krošanja. Prema dobivenom regresijskom modelu, u slučaju kada imamo 22 ECM vrste po plohi piknide se ne razvijaju na iglicama crnoga bora, a u slučaju kada imamo 20 ECM vrsta po plohi osutost se smanjuje ispod $10 \%$. Linearni regresijski model pokazuje da ukoliko Shannon indeks za ukupan broj vrsta prelazi 2,4, osutost krošanja raste iznad $25 \%$, a ukoliko on iznosi iznad 3,0, osutost se može povećati iznad $30 \%$. Promatrajući linearni regresijski model povezanosti Shannon indeksa ECM vrsta i piknida S. sapinea, možemo zaključiti kako povećanjem vrijednosti indeksa iznad 2,4 piknide izostaju s iglica te isti može poslužiti kako dobar pokazatelj zdravstvenog stanja istraživanih kultura crnoga bora. Na temelju dobivenih rezultata zaključujemo kako je potrebno provesti daljnja istraživanja opisanih odnosa na većem broju ploha i tijekom dužeg razdoblja. Na taj bi način bilo moguće dobiti pouzdanije podatke koji bi mogli poslužiti za razvijanje novih metoda i modela integrirane zaštite šuma u sve izraženijim ekološkim promjenama u staništima crnoga bora.

KLJUČNE RIJEČI: Pinus nigra, Sphaeropsis sapinea, osutost krošanja, integrirana zaštita šuma, bogatstvo vrsta, Shannon indeks, ektomikorizne gljive 